Correction

\title{
Correction: Jiménez, F., et al. System for Road Vehicle Energy Optimization Using Real Time Road and Traffic Information. Energies 2014, 7, 3576-3598
}

\author{
Felipe Jiménez *, Wilmar Cabrera-Montiel and Santiago Tapia-Fernández \\ Received: 23 December 2015; Accepted: 4 January 2016; Published: 21 January 2016 \\ Academic Editor: Enrico Sciubba \\ University Institute for Automobile Research (INSIA), Technical University of Madrid (UPM), Madrid 28031, \\ Spain; wilmar.cabrera@upm.es (W.C.-M.); santiago.tapia@upm.es (S.T.-F.) \\ * Correspondence: felipe.jimenez@upm.es; Tel.: +34-913-365-300; Fax: +34-913-365-302
}

In the original version of the article [1], insufficient acknowledgement was given for the original Dynamic Programming optimization tool. We apologize for this error. To correct this fact, Santiago Tapia-Fernández has been added as an author, and the acknowledgements and authors contributions have been corrected.

The corrected authors list, acknowledgements and authors' contributions are provided below:

Authors list: Felipe Jiménez, Wilmar Cabrera-Montiel and Santiago Tapia-Fernández

Acknowledgments: This research has been partially funded by the Spanish Ministry of Science and Innovation through the SAMPLER project (reference TRA2010-0225-C03-03).

Authors' Contributions: Felipe Jimenez proposed the system architecture. Wilmar Cabrera-Montiel and Santiago Tapia-Fernández developed the Dynamic Programming optimization tool. All authors carried out data analysis and discussed the results.

The authors would like to apologize for any inconvenience caused to the readers by these changes.

\section{Reference}

1. Jiménez, F.; Cabrera-Montiel, W. System for Road Vehicle Energy Optimization Using Real Time Road and Traffic Information. Energies 2014, 7, 3576-3598. [CrossRef]

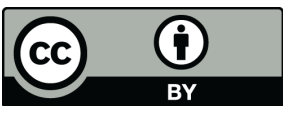

(C) 2016 by the authors; licensee MDPI, Basel, Switzerland. This article is an open access article distributed under the terms and conditions of the Creative Commons by Attribution (CC-BY) license (http:/ / creativecommons.org/licenses/by/4.0/). 